\title{
Periode Piutang, Periode Persediaan, Periode Utang terhadap Profitabilitas dan Nilai Perusahaan pada Perusahaan Industri Barang Konsumsi di Bursa Efek Indonesia
}

\author{
Dita Roosemella Paramadina, Ubud Salim, Achmad Helmy Djawahir \\ Program Studi Magister Manajemen, Fakultas Ekonomi dan Bisnis, Universitas Brawijaya
}

\begin{abstract}
Abstrak
Perusahaan sektor industri barang konsumsi di Indonesia cenderung meningkatkan penggunaan modal kerjanya pada tahun 2009-2013. Umumnya, adanya peningkatan profitabilitas karena adanya efisiensi manajemen modal kerja, maka peningkatan profitabilitas tersebut juga meningkatkan nilai perusahaan. Penelitian ini bertujuan menganalisis pengaruh langsung periode piutang, periode persediaan, periode utang terhadap profitabilitas dan nilai perusahaan. Selain itu, pengaruh tidak langsung terhadap nilai perusahaan melalui profitabilitas juga diteliti. Sebanyak 23 perusahaan sektor industri barang konsumsi yang terdaftar di Bursa Efek Indonesia digunakan dalam penelitian sebagai populasi dan sampel. Analisis jalur digunakan sebagai metode analisis data. Hasil penelitian membuktikan bahwa peningkatan periode piutang dan periode utang dapat meningkatkan profitabilitas perusahaan. Penurunan periode piutang dan periode persediaan serta peningkatan periode utang akan meningkatkan nilai perusahaan. Profitabilitas tidak memediasi pengaruh periode piutang, periode persediaan, periode utang terhadap nilai perusahaan. Disimpulkan bahwa perusahaan dapat meningkatkan penggunaan jumlah modal kerjanya selama peningkatan modal kerjanya tidak melebihi pertumbuhan penjualannya dan likuiditas menjadi penilaian utama bagi investor.
\end{abstract}

Kata kunci: periode piutang, periode persediaan, periode utang, profitabilitas, nilai perusahaan.

\section{Abstract}

Consumer goods firms in Indonesia tended to increase the use of working capital in 2009-2013. Generall, the increasing profitability due to the efficiency of working capital management, the increasing profitability also increases the firm value. The purpose of this research is to examine the direct effect of receivable period, inventory period, payables period to profitability and firm value. In addition, the indirect effect on firm value through profitability is also examined. A total of 23 companies in the consumer goods industry sectors listed on the Indonesia Stock Exchange are used as population and sample. Path analysis is used as an data analysis method. Results proved that increasing receivable period and payables period increase the firms's profitability. Decreasing receivables period and inventory period, and increasing payables period increase firm value. Profitability does not significantly mediate receivables period, inventory period, payabels period to the value of the company. It's concluded that firms can increase their working capital amount if the growth of the increasing working capital does not exceed the sales growth. Liquidity is the investor's main assessing.

Keywords: receivables period, inventory period, payables period, profitabiliy, firm value.

\section{PENDAHULUAN}

Teori secara umum menyatakan bahwa efisiensi manajemen modal kerja dapat meningkatkan profitabilitas dan nilai perusahaan [1]. Dengan efisiensi tersebut, perusahaan dapat menekan pengeluaran biaya investasi sehingga perolehan laba akan meningkat. Perolehan laba perusahaan yang meningkat tentu dapat meningkatkan nilai perusahaan [2]. Namun, terdapat kondisi tertentu ketika perusahaan tidak melakukan efisiensi manajemen modal kerja. Perusahaan yang sedang mengembangkan bisnisnya terutama untuk mendongkrak penjualan akan menaikkan penggunaan modal kerjanya [3] selama manfaatnya lebih besar daripadan biaya peningkatan investasi modal kerja yang dikeluarkan [4].

Sektor industri barang konsumsi merupakan salah satu sektor favorit investor di Bursa Efek Indonesia karena dinilai tahan krisis dan berkontribusi besar dalam meningkatkan nilai indeks harga saham gabungan [5]. Perkembangan sektor ini bergantung pada daya beli masyarakat yang juga dipengaruhi oleh pendapatan domestik bruto, suku bunga dan kondisi ekonomi makro [6]. Adanya peningkatan kesejahteraan masyarakat yang ditunjukkan dengan kenaikan PDB hingga sebesar 36 juta per kapita pada tahun 2013 [7],

Alamat Korespondensi Penulis:

Dita Roosemella Paramadina

Email : ditaroosemella@gmail.com

Alamat : J. MT. Haryono No. 165, Malang 65145, Indonesia 
membuat perusahaan di sektor ini ikut berkembang. Kondisi tersebut tentu dapat memengaruhi kebijakan perusahaan dalam mengelola modal kerjanya. Tabel 1 menunjukkan adanya peningkatan penggunaan modal kerja disertai dengan peningkatan penjualan dan laba bersih yang terjadi selama tahun 2009-2013. Berdasarkan data pada tabel tersebut, perusahaan di sektor industri barang konsumsi cenderung tidak melakukan efisiensi manajemen modal kerjanya sehingga dapat mengganggu likuiditas perusahaan.

Tabel 1. Rata-rata Modal Kerja Bersih, Rata-rata Penjualan, Rata-rata Laba Bersih Perusahaan Sektor Industri Barang Konsumsi (dalam Ratusan Jutaan Rupiah)

\begin{tabular}{lccccc}
\hline & $\mathbf{2 0 0 9}$ & $\mathbf{2 0 1 0}$ & $\mathbf{2 0 1 1}$ & $\mathbf{2 0 1 2}$ & $\mathbf{2 0 1 3}$ \\
\hline $\begin{array}{l}\text { Modal } \\
\text { kerja }\end{array}$ & 1.336 & 1.543 & 1.830 & 2.114 & 2.537 \\
$\begin{array}{l}\text { Bersih } \\
\text { Penjualan }\end{array}$ & 5.181 & 6.180 & 7.201 & 8.423 & 9.692 \\
$\begin{array}{l}\text { Laba } \\
\text { Bersih }\end{array}$ & 526 & 704 & 866 & 853 & 972 \\
\hline
\end{tabular}

Sumber: Data diolah (2014)

Konsep siklus perubahan kas sering menjadi acuan oleh banyak penelitian untuk mengukur efisiensi manajemen modal kerja perusahaan secara menyeluruh [4]. Semakin pendek siklus perubahan kas menunjukkan semakin efisien manajemen modal kerja perusahaan. Untuk mendapatkan siklus perubahan kas yang pendek, perusahaan perlu melakukan penagihan piutang usaha lebih cepat, mengurangi jumlah persediaan dan menunda pembayaran utangnya kepada pemasok. Penelitian sebelumnya menemukan bahwa semakin pendek siklus perubahan kas maka profitabilitas perusahaan akan semakin meningkat [8]. Namun juga ada beberapa penelitian yang menemukan bahwa semakin panjang siklus perubahan kas semakin meningkat profitabilitas [9][10]. Selain profitabilitas, bukti empirik lainnya menemukan bahwa semakin pendek siklus perubahan kas maka nilai perusahaan akan semakin meningkat [11], tetapi ada penelitian lain yang menunjukkan bahwa perpanjangan siklus perubahan kas dapat meningkatkan nilai perusahaan [12].

Selain menghubungkan siklus perubahan kas dengan kinerja perusahaan, penelitian terdahulu juga menggunakan komponen siklus perubahan kas untuk mengetahui secara lebih rinci penerapan efisiensi manajemen modal kerja perusahaan. Dari segi periode piutang, perusahaan yang menagih piutangnya lebih cepat akan meningkatkan profitabilitasnya [13][14], tetapi dengan perpanjangan piutang usaha perusahaan juga dapat meningkatkan profitabilitas [9]. Dari segi periode persediaan, semakin rendah penggunaan persediaan akan semakin meningkatkan profitabilitas perusahaan [8][14][15], tetapi meningkatkan persediaan juga dapat meningkatkan profitabilitas[9]. Dari segi periode utang, semakin lama penundaan pembayaran utang perusahaan dapat meningkatkan profitabilitasnya [14][16] meskipun sebagian besar hasil penelitian lebih mendukung pembayaran utang lebih cepat [13][15].

Dari segi hubungan komponen siklus perubahan kas dengan kinerja perusahaan melalui nilai perusahaan, hanya sedikit penelitian yang menguji hal tersebut. Suatu penelitianhanya menemukan bahwa pembayaran piutang lebih cepat dan efisiensi penggunaan persediaan dapat meningkatkan nilai perusahaan [18], sedangkanpenelitian lain yang serupa tetapi tidak menemukan hasil yang signifikan pada seluruh komponen siklus perubahan kas [9][12]. Hal ini memberikan celah penelitian bahwa investor kemungkinan tidak mempertimbangkan likuiditas perusahaan secara langsung dalam penilaiannya, tetapi melalui profitablitasnya. Sesuai dengan pernyataan Fama dan French [2], Brigham dan Ehrhardt [1] serta Almeida dan Eid [18] yakni jika profitabilitas perusahaan meningkat karena adanya efisiensi manajemen modal kerja, maka peningkatan profitabilitas tersebut juga meningkatkan nilai perusahaan.

Berdasarkan pemaparan tersebut, terdapat beberapa rumusan masalah yang menarik untuk diteliti terkait dengan manajemen modal kerja melalui komponen siklus perubahan kas yakni periode piutang, periode persediaan dan periode utang. Pertama, meneliti hubungan komponen siklus perubahan kas dengan profitabilitas. Kedua, meneliti hubungan komponen siklus perubahan kas dengan nilai perusahaan untuk melengkapi bukti empirik sebelumnya yang sangat sedikit terutama terkait dengan komponen siklus perubahan kas. Ketigameneliti hubungan profitabilitas dengan nilai perusahaan. Keempat meneliti hubungan tidak langsung antara komponen siklus perubahan kas dengan nilai perusahaan melalui profitabilitas yang sebelumnya belum pernah diteliti oleh peneliti-penelitian terdahulu. Oleh karena itu, penelitian ini bertujuan untuk meneliti pengaruh langsung komponen siklus perubahan kas terhadap profitabilitas dan nilai perusahaan serta pengaruh tidak langsungnya terhadap nilai perusahaan melalui profitabilitas. 


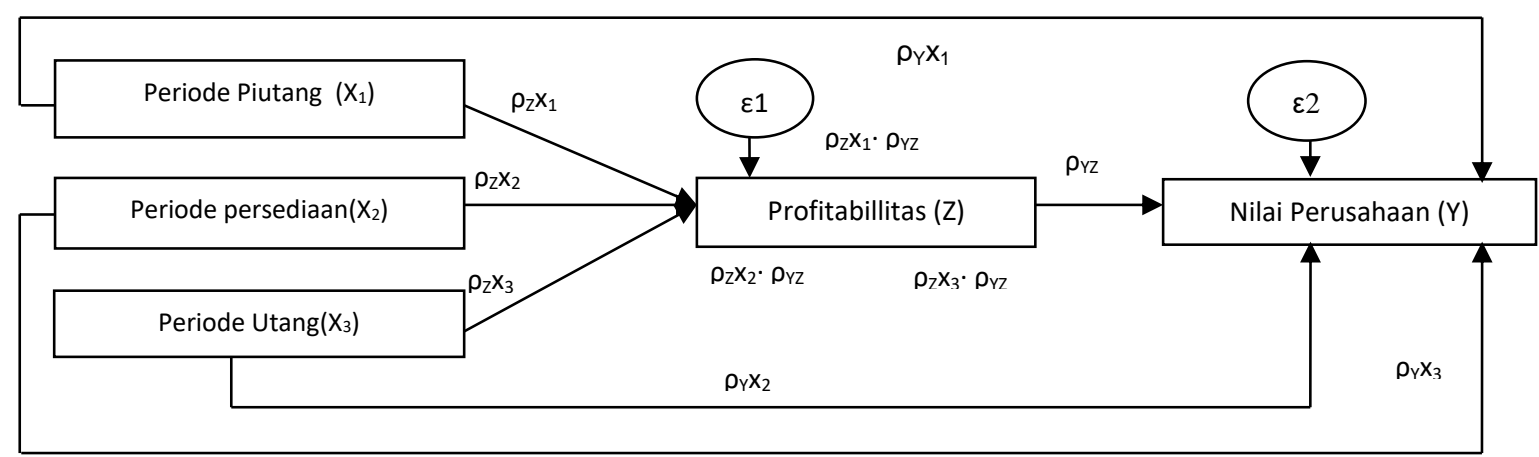

Gambar 1.Diagram Model Analisis Jalur. Keterangan, $\rho$ : koefisien jalur (path coefficient) yang menyatakan hubungan pengaruh langsung; $P_{Z X_{n}}$ : menyatakan besarnya hubungan pengaruh langsung $X_{n}$ terhadap $Z$; $P_{Y_{x n}}$ : menyatakan besarnya hubungan pengaruh langsung $X_{n}$ terhadap $Y ; P_{Y Z}$ : menyatakan besarnya hubungan pengaruh langsung $Y$ teradap Z; $P_{Z X n}$. $\rho_{Y z}$ : menyatakan besarnya pengaruh tidak langsung $X_{n}$ terhadap $Y$ melalui $Z ; E_{n}$ : jumlah varian variabel endogen yang tidak dapat dijelaskan variabel eksogen.

\section{METODE PENELITIAN}

Penelitian ini menggunakan pendekatan kuantitatif (positivis) dengan jenis penelitian eksplanatori (explanatory research). Analisis jalur (path analysis) digunakan sebagai metode analisis data karena dapat menguji pengaruh variabel mediasi. Penggambaran kerangka konsep dan diagram analisis jalur disajikan pada Gambar 1. Terdapat dua persamaan regresi yang menunjukkan hubungan-hubungan variabel yang diuji dalam penelitian. Persamaan regresi pertama menguji variabel eksogen terhadap variabel mediasi, sedangkan regresi kedua menguji variabel eksogen dan variabel mediasi terhadap variabel endogen. Berikut ini adalah persamaan regresi yang digunakan dalam penelitian.

(1) $Z=\alpha+\rho_{Z X 1}+\rho_{Z X 2}+\rho_{Z X 4}+\varepsilon_{1}$

(2) $Y=\alpha+\rho_{Y X 1}+\rho_{Y X 2}+\rho_{Y X 3}+\rho_{y Z}+\varepsilon_{2}$

Setelah disusun persamaan regresi, dilakukan pengujian beberapa asumsi analisis jalur yakni hubungan antar variabel yang diteliti memiliki bentuk linier, model berbentuk rekursif atau menunjukkan aliran kausal satu arah, variabel diukur tanpa kesalahan, variabel endogen minimal berskala interval dan model sesuai dengan teori yang relevan [19].

Tahap selanjutnya melakukan uji regresi dan pemeriksaan validitas model melalui penghitungan koefisien determinasi total $\left(R_{m}^{2}\right)$. Koefisien tersebut dihitung dengan nilai satu dikurangi perkalian dari kuadrat nilai galat $\left(\mathrm{P}^{2} \mathrm{ep}\right)$ masing-masing persamaan regresi dimana nilai galat atau diperoleh melalui rumus $\varepsilon_{n}=\sqrt{\left(1-R^{2}\right)}$.

$$
R_{m}^{2}=1-P_{e 1}^{2} P_{e 2}^{2} \ldots P_{e p}^{2}
$$

Jika pengujian-pengujian sebelumnya telah dilakukan, maka akan didapat hasil dari uji pengaruh langsung antar variabel penelitian baik dari nilai koefisien standardized yang merupakan koefisien jalur $(\rho)$ maupun tingkat signifikansinya. Pengujian pengaruh tidak langsung melalui uji mediasi dapat dilakukan dengan menggunakan Uji Sobel [20]. Dari Uji Sobel tersebut dapat diperoleh nilai t-hitung dan nilai signifikansi dari pengaruh tidak langsung suatu variabel, sedangkan nilai koefisien tidak langsung diperoleh melalui perkalian koefisien standardized pengaruh langsungnya.

\section{Metode Pengumpulan Data}

Obyek penelitian ini adalah perusahaan sektor industri barang konsmsi yang terdaftar di Bursa Efek Indonesia (BEI) dengan periode penelitian tahun 2009-2013. Terdapat 38 perusahaan sektor industri barang konsumsi yang diseleksi sehingga diperoleh populasi penelitian sebanyak 23 perusahaanberdasarkan kelengkapan data selama periode penelitian, persamaan karakteristik perusahaan dan tidak terdapat data outlier. Perusahaan rokok dan perusahaan peralatan rumah tangga dikeluarkan dari populasi karena memiliki karakteristik yang jauh berbeda dengan tiga sub sektor lainnya yang tergolong barang konsumsi dengan pergerakan cepat (Fast Moving Consumer Goods/FMCG) seperti sub sektor makanan dan minuman, farmasi serta kosmetik dan kebutuhan rumah tangga.

Metode sensus digunakan dalam pengambilan sampel sehingga seluruh jumlah populasi penelitian dijadikan sebagai sampel dengan unit analisis sejumlah 115 observasi. Metode pengumpulan data pada penelitian menggunakan metode dokumentasi karena sumber data yang digunakan merupakan data sekunder dengan jenis data kuantitatif. Data diperoleh melalui laporan keuangan yang sudah 
diaudit dan laporan tahunan perusahaan yang diperoleh dari database BEI.

Definisi operasional variabel penelitian dan pengukurannya disajikan pada Tabel 3. GOP digunakan sebagai pengukuran profitabilitas karena dalam penelitian ini ingin berfokus pada pengukuran kinerja operasional, sehingga tidak menggunakan ROA yang lebih menggambarkan kinerja perusahaan secara menyeluruh [8]. Nilai perusahaan diukur dengan Tobin's $Q$ yang sering digunakan oleh peneliti lainnyakarena dapat menggambarkan bagaimana pasar melakukan ekspektasi nilai masa depan melalui penilaian manajemen modal kerja yang dilakukan oleh perusahaan [9][17].

Tabel 3.Definsi Operasional Variabel Penelitian dan Pengukuran Variabel Penelitian

\begin{tabular}{|c|c|c|c|}
\hline Variabel & Proksi & Pengukuran & Acuan \\
\hline \multicolumn{4}{|l|}{ Mediasi } \\
\hline $\begin{array}{l}\text { Profitabilitas (Z) merupakan } \\
\text { kemampuan perusahaan dalam } \\
\text { menghasilkan laba dari kegiatan } \\
\text { operasional. }\end{array}$ & $\begin{array}{l}\text { Gross } \\
\text { operating } \\
\text { profit (GOP) }\end{array}$ & $\begin{array}{l}\text { (Sales - Cost of Good Sold) / } \\
\text { (Total Asset - Financial Asset) } \\
\text { (data dalam persentase) }\end{array}$ & Abuzayed [9] \\
\hline \multicolumn{4}{|l|}{ Endogen } \\
\hline $\begin{array}{l}\text { Nilai Perusahaan }(\mathrm{Y}) \text { merupakan } \\
\text { penilaian kinerja masa lalu dan } \\
\text { prospek perusahaan di masa yang } \\
\text { akan datang. }\end{array}$ & Tobin's Q & $\begin{array}{l}\text { (Market Value of Equity + Book } \\
\text { Value of Liability) / Book Value } \\
\text { of Assets } \\
\text { (data dalam persentase) }\end{array}$ & $\begin{array}{c}\text { Mohammad } \\
\text { dan Mohd Saad } \\
{[11]}\end{array}$ \\
\hline \multicolumn{4}{|l|}{ Eksogen } \\
\hline $\begin{array}{l}\text { Periode Piutang }(\mathrm{X} 1) \text { merupakan } \\
\text { rata-rata waktu yang dibutuhkan } \\
\text { perusahaan untuk mengubah } \\
\text { piutang usaha menjadi kas. }\end{array}$ & $\begin{array}{l}\text { Receivable } \\
\text { conversion } \\
\text { period }\end{array}$ & $\begin{array}{l}\text { Receivables } \\
\text { Sales } / 365 \\
\text { (data dalam satuan hari) }\end{array}$ & Deloof [4] \\
\hline $\begin{array}{l}\text { Periode Persediaan }(\mathrm{X} 2) \text { merupakan } \\
\text { rata-rata waktu yang diperlukan } \\
\text { perusahaan untuk menjual } \\
\text { persediaan barang jadinya. }\end{array}$ & $\begin{array}{l}\text { Inventory } \\
\text { conversion } \\
\text { period }\end{array}$ & $\begin{array}{l}\text { Inventory } \\
\text { Costofgoodssold } / 365 \\
\text { (data dalam satuan hari) }\end{array}$ & Deloof [4] \\
\hline $\begin{array}{l}\text { Periode Utang (X3) merupakan rata- } \\
\text { rata waktu yang dibutuhkan untuk } \\
\text { membeli bahan baku serta } \\
\text { pembayarannya. }\end{array}$ & $\begin{array}{l}\text { Payables } \\
\text { defferal } \\
\text { period }\end{array}$ & $\begin{array}{l}\text { Payables } \\
\text { Costofgoodssold /365 } \\
\text { (data dalam satuan hari) }\end{array}$ & Deloof [4] \\
\hline
\end{tabular}

Sumber: Data diolah, 2014

\section{HASIL DAN PEMBAHASAN}

Tabel 4 menunjukkan periode piutang, periode persediaan dan periode utang memiliki nilai deviasi standar yang sangat tinggi. Nilai tersebut menjelaskan data yang sangat heterogen karena nilainya jauh di atas 1,0. Hal serupa juga terjadi pada nilai deviasi standar dari nilai perusahaan meskipun tidak setinggi tiga variabel sebelumnya, sedangkan nilai deviasi standar profitabilitas menunjukkan data yang homogen. Penelitian ini mengonversi data setiap variabel menjadi bentuk logaritma natural (In) agar lebih homogen dan jarak data antar variabel tidak terlalu jauh sekaligus dapat mengobati pelanggaran asumsi klasik [21].

Tabel 5 menjelaskan rata-rata periode piutang, periode persediaan dan periode utang per tahun yang terjadi di setiap sub sektor. Pada tabel tersebut terlihat bahwa ketiga sub sektor secara umum terjadi kenaikan jumlah periode yang berarti bahwa perusahaan juga meningkatkan jumlah penggunaan modal kerjanya terutama pada piutang dan persediaan. Di samping itu, periode utang perusahaan juga meningkat untuk mengimbangi peningkatan periode piutang dan perode persediaan agar penggunaan modal kerja dapat lebih terkontrol.

Sub sektor farmasi serta kosmetik dan kebutuhan rumah tangga cenderung memiliki periode piutang, periode persediaan dan periode utang yang lebih lama daripada sub sektor makanan dan minuman. Penyebabnya adalah perusahaan makanan dan minuman memiliki tingkat perputaran persediaan barang jadi yang lebih tinggi daripada perusahaan di dua sub sektor lainnya karenatingginya tingkat intensitas pembelian produk, sehingga perusahaan lebih 
cepat melakukan penagihan piutang dan pembayaran utangnya kepada pemasok.

Tabel 4.Statistik Deskriptif Variabel Penelitian

\begin{tabular}{lccc}
\hline Variabel & N & $\begin{array}{l}\text { Rata- } \\
\text { rata }\end{array}$ & $\begin{array}{l}\text { Deviasi } \\
\text { Standar }\end{array}$ \\
\hline Periode piutang & 115 & 58,37 & 35,35 \\
Periode persediaan & 115 & 43,03 & 30,62 \\
Periode utang & 115 & 41,54 & 27,43 \\
Profitabilitas & 115 & 0,86 & 0,67 \\
Nilai perusahaan & 115 & 2,78 & 3,32 \\
Periode piutang (In) & 115 & 3,94 & 0,68 \\
Periode persediaan (In) & 115 & 3,61 & 0,69 \\
Periode utang (In) & 115 & 3,54 & 0,86 \\
Profitabilitas (In) & 115 & 1,34 & 0,17 \\
Nilai perusahaan (In) & 115 & 1,65 & 0,41 \\
\hline
\end{tabular}

Sumber: Data diolah, 2015

Tabel 5 juga menjelaskan bahwa profitabilitas yang diwakili oleh nilai rata-rata GOP cenderung stabil setiap tahun di setiap sub sektor. Dari tabel tersebut perusahaan di sub sektor makanan dan minuman cenderung memiliki tingkat profitabilitas yang cenderung lebih rendah daripada perusahaan di dua sub sektor lainnya. Seperti yang dinyatakan oleh Stevenson [22] bahwa perusahaan yang perputaran persediaannya tinggi biasanya memiliki profit margin yang rendah. Nilai perusahaan yang diwakili oleh nilai Tobin's Q cenderung mengalami kenaikan setiap tahunnya di setiap sub sektor dilihat dari nilai rata-rata setiap tahunnya. Kenaikan ini menunjukkan bahwa investor di pasar mengapresiasi positif saham-saham perusahaan sektor industri barang konsumsi. Sub sektor kosmetik dan kebutuhan rumah tangga memiliki nilai yang paling tinggi di antara dua sub sektor lainnya.

Gambar 2 menunjukkan gambaran kondisi periode piutang, persediaan dan utang perusahaan sektor barang konsumsi secara menyeluruh. Terlihat bahwa periode piutang dan periode persediaan yang cenderung meningkat selama tahun 2009 hingga 2011 dan menurun sejak tahun 2012, sedangkan periode pembayaran utang cenderung terus meningkat selama periode penelitian. Panjang periode piutang dan periode persediaan belum dapat diimbangi dengan panjang periode utang sehingga menyebabkan siklus perubahan kas yang cukup tinggi pada tahun 2009-2011. Namun sejak tahun 2012, siklus perubahan kas mengalami penurunan karena perusahaan dapat mengurangi penggunaan piutang dan persediaannya yang menunjukkan adanya upaya perusahaan dalam melakukan efisiensi penggunaan modal kerjanya.

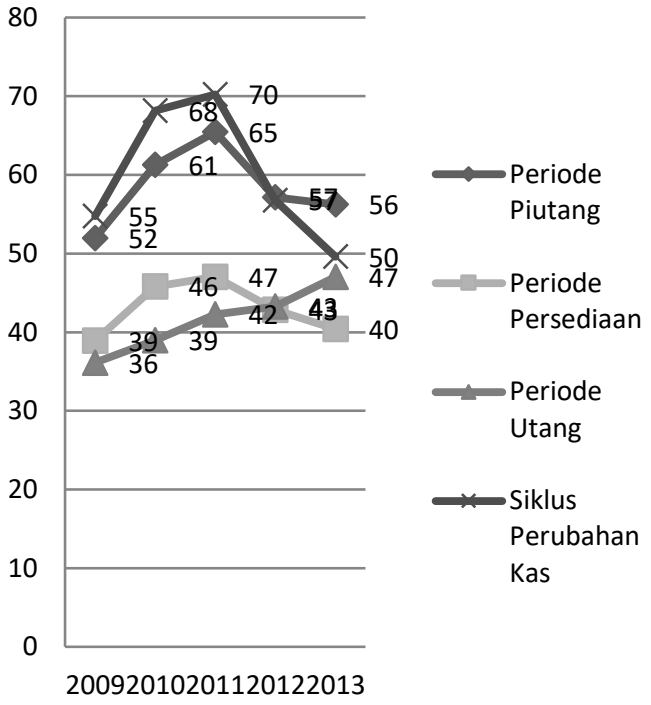

Sumber:Data diolah, 2015

Gambar 2.Grafik Siklus Perubahan Kas dan Komponennya (dalam Hari)

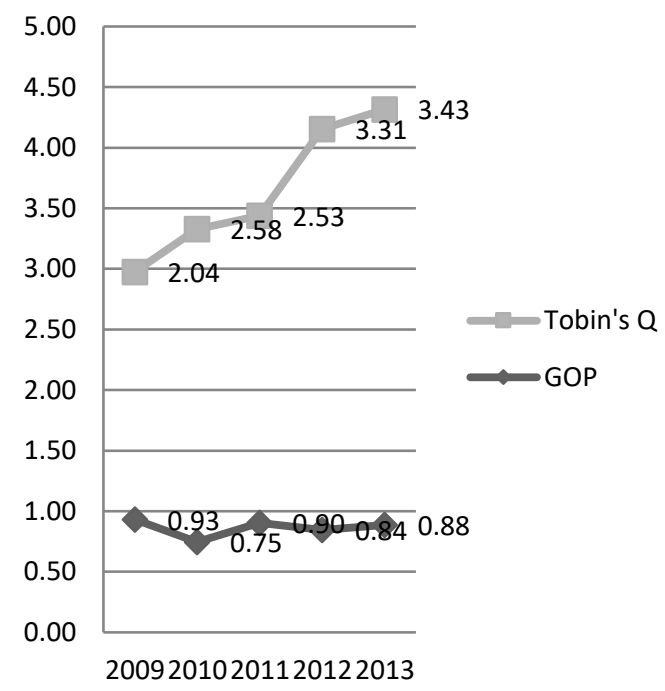

Sumber:Data diolah, 2015

Gambar 3.Grafik Gross Operating Profit (GOP) dan Tobin's $\mathrm{Q}$ (dalam Persen)

Gambar 3 memperlihatkan rata-rata nilai laba operasi kotor atau GOP cenderung stabil di kisaran angka $80 \%$-an selama periode penelitian. Hal ini menunjukkan bahwa perusahaan berupaya menjaga profitabilitas operasionalnya agar tetap tinggi sehingga dapat menutupi pengeluarannya. Adanya peningkatan rata-rata nilai Tobin's $Q$ juga menunjukkan optimisme investor di pasar modal terhadap saham-saham perusahaan sektor industri barang konsumsi. Umumnya perusahaan yang semula memiliki nilai sekitar $200 \%$ di tahun 2009 meningkat menjadi sekitar 300\% di tahun 2013. Dengan kata lain investor menganggap 
bahwa sektor ini memiliki prospek yang baik di masa yang akan datang.

Pengujian data telah memenuhi asumsi analisis jalur dimana masing-masing hubungan antar variabel memiliki bentuk linier melalui uji linieritas, model berbentuk rekursif, variabel berskala interval dan terukur secara akurat, serta sesuai dengan teori yang digunakan. Penelitian ini menggunakan persamaan regresi bentuk logaritma natural (In), tetapi pada hubungan variabel $X_{1}$ dengan variabel $Y$, variabel $X_{1}$ tetap menggunakan bentuk dasar, sedangkan variabel $Y$ menggunakan logaritma natural. Hal tersebut disebabkan jika variabel $X_{1}$ tetap menggunakan bentuk logaritma natural, hasil uji linieritasnya tidak linier sehingga tidak memenuhi asumsi analisis jalur.

Tabel 5.Rata-rata Penghitungan Data Per Sub Sektor

\begin{tabular}{|c|c|c|c|c|c|}
\hline \multirow{2}{*}{ Sub Sektor } & \multicolumn{5}{|c|}{ Rata-rata per tahun } \\
\hline & 2009 & 2010 & 2011 & 2012 & 2013 \\
\hline & \multicolumn{5}{|c|}{ Periode Perubahan Piutang (dalam Hari) } \\
\hline Makanan dan Minuman & 43 & 60 & 64 & 44 & 44 \\
\hline Farmasi & 62 & 58 & 63 & 70 & 68 \\
\hline \multirow[t]{2}{*}{ Kosmetik dan Kebutuhan Rumah Tangga } & 70 & 74 & 80 & 84 & 83 \\
\hline & \multicolumn{5}{|c|}{ Periode Perubahan Persediaan (dalam Hari) } \\
\hline Makanan dan Minuman & 32 & 46 & 40 & 38 & 30 \\
\hline Farmasi & 49 & 45 & 57 & 51 & 55 \\
\hline \multirow[t]{2}{*}{ Kosmetik dan Kebutuhan Rumah Tangga } & 44 & 47 & 52 & 44 & 50 \\
\hline & \multicolumn{5}{|c|}{ Periode Pembayaran Utang (dalam Hari) } \\
\hline Makanan dan Minuman & 21 & 25 & 25 & 28 & 27 \\
\hline Farmasi & 50 & 49 & 57 & 55 & 63 \\
\hline \multirow[t]{2}{*}{ Kosmetik dan Kebutuhan Rumah Tangga } & 39 & 42 & 48 & 45 & 59 \\
\hline & \multicolumn{5}{|c|}{ Profitabilitas (dalam Persen) } \\
\hline Makanan dan Minuman & 0,63 & 0,41 & 0,69 & 0,54 & 0,74 \\
\hline Farmasi & 1,32 & 1,23 & 1,18 & 1,22 & 1,07 \\
\hline \multirow[t]{2}{*}{ Kosmetik dan Kebutuhan Rumah Tangga } & 1,31 & 1,07 & 1,18 & 1,27 & 1,09 \\
\hline & \multicolumn{5}{|c|}{ Nilai Perusahaan (dalam Persen) } \\
\hline Makanan dan Minuman & 1,84 & 2,33 & 2,26 & 3,33 & 3,58 \\
\hline Farmasi & 1,28 & 1,69 & 1,78 & 2,35 & 2,06 \\
\hline Kosmetik dan Kebutuhan Rumah Tangga & 4,71 & 5,78 & 5,49 & 5,48 & 5,99 \\
\hline
\end{tabular}

Sumber: Data diolah, 2015

Tabel 6 menjelaskan hasil koefisien determinasi maupun koefisien determinasi total persamaan regresi bentuk In. Penggunaan bentuk In pada persamaan regresi dapat memberikan hasil validitas yang lebih baik. Dari penghitungan koefisien determinasi totalnya $\left(\mathrm{R}_{\mathrm{m}}^{2}\right)$, diperoleh nilai sebesar 0,422. Berdasarkan hal tersebut, model penelitian yang disusun dapat menjelaskan sebesar $42,20 \%$ sisanya dijelaskan oleh variabel lain yang tidak diteliti dan adanya error.

Hasil pengujian pada Gambar 4 menunjukkan bahwa periode piutang dan periode utang berpengaruh positif signifikan terhadap profitabilitas, sedangkan periode persediaan berpengaruh positif tidak signifikan terhadap profitabilitas. Ditemukannya arah hubungan positif pada periode piutang dan periode persediaan sesuai dengan pernyataan yang diungkapkan oleh Vernimmen, et al. [3] dan Deloof [4] bahwa perusahaan yang mengembangkan bisnisnya untuk meningkatkan penjualan sering kali membutuhkan modal kerja yang lebih tinggi selama peningkatan tersebut manfaatnya lebih besar daripada biaya implisitnya. Berdasarkan hasil yang diperoleh, peningkatan periode piutang memberikan dampak positif pada profitabilitas sehingga dapat mendukung hasil peneltian terdahulu [9], tetapi 
Periode Piutang, Periode Persediaan, Periode Utang terhadap Profitabilitas dan Nilai Perusahaan pada Perusahaan Industri Barang Konsumsi di Bursa Efek Indonesia (Paramadina, et al.)

peningkatan periode persediaan tidak memberikan dampak apapun pada profitabilitas.

Tidak signifikannya periode persediaan terhadap profitabilitaspada penelitian ini kemungkinan dapat disebabkan oleh adanya kelebihan jumlah persediaan yang dimiliki oleh perusahaan-perusahaan sektor industri barang konsumsi. Kelebihan ini terjadi karena perusahaan harus menghadapi jumlah permintaan barang yang tidak menentu dan menekan risiko kekurangan persediaan di pasar sehingga perusahaan perlu untuk memiliki cadangan persediaan [22]. Selain itu, lamanya penjualan produk dapat menjadi penyebab lainnya. Kelebihan jumlah persediaan ini juga memungkinkan perusahaan meningkatkan jumlah piutangnya agar dapat mengurangi kelebihan tersebut [23]. Dengan meningkatkan piutang usaha sebagai stimulasi pembelian oleh pelanggan, perusahaan dapat menjual persediaan lebih banyak sekaligus dapat mengurangi jumlah persediaan yang berlebih.

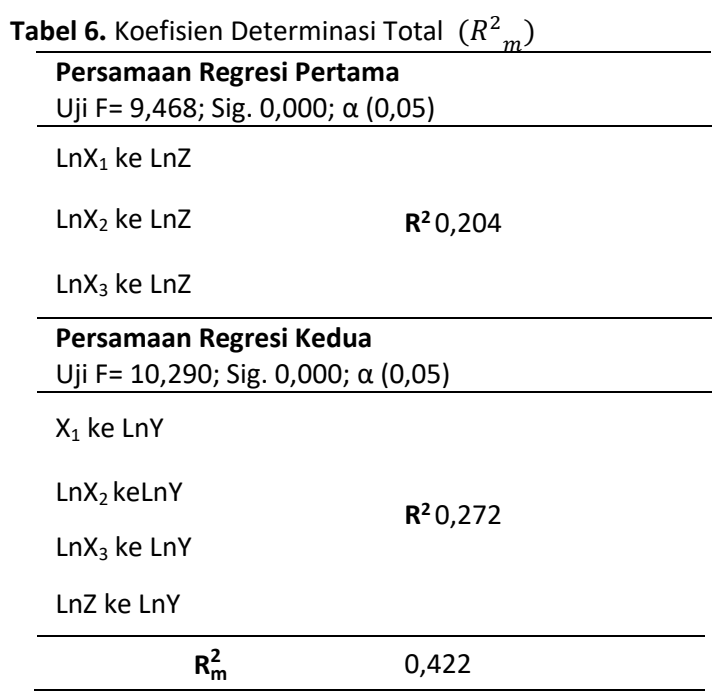

Sumber: Data diolah, 2015

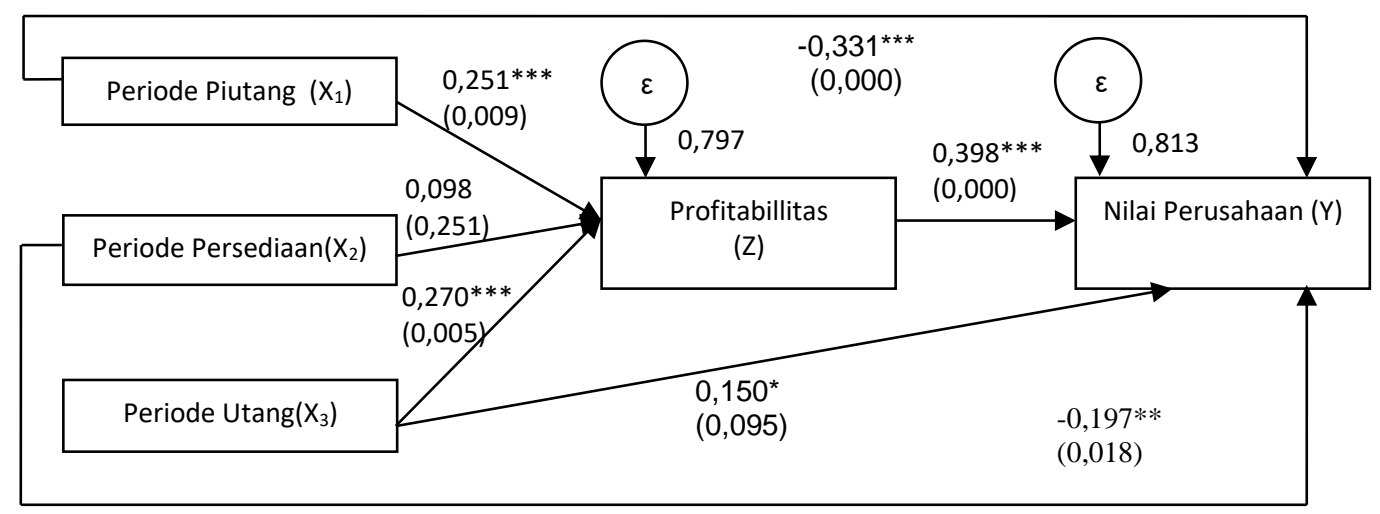

Gambar 4.Grafik Gross Operating Profit (GOP) dan Tobin's Q. Keterangan: *Signifikan pada 10\%, **Signifikan pada 5\%, $* * *$ Signifikan pada $1 \%$

Penelitian ini menemukan bahwa periode utang berpengaruh positif signifikan terhadap profitabilitas [12][16].Umumnya, penelitian terdahulu menemukan pengaruh negatif yang signifikan dan menganggap bahwa perusahaan yang kondisi profitabilitasnya baik akan lebih cepat pembayaran utangnya [4]. Hal tersebut tentu berbeda dengan apa yang terjadi pada periode utang perusahaan sektor industri barang konsumsi di Indonesia yang cederung meningkat dimana justru perusahaan dengan profitabilitas baiklah yang lebih dipercaya pemasok untuk menerima perpanjangan pembayaran utang [23].

Seperti yang juga diungkapkan beberapa penelitian, peningkatan utang kepada pemasok biasanya juga diikuti oleh peningkatan piutang usaha karena utang dagang dapat digunakan sebagai salah satu sumber pembiayaan jangka pendek, selama perusahaan memiliki jumlah kas yang berlebih [24][25]. Perusahaan yang memiliki kas yang berlebih dapat mengalihkan kasnya melalui penambahan piutang usaha maupun memberikan perpanjangan pembayaran utang pelanggannya. Seperti yang ditunjukkan pada Gambar 4, signifikansi pengaruh periode piutang maupun periode utang terhadap profitabilitas sama-sama memiliki tingkat signifikansi yang sangat tinggi yakni pada $1 \%$.

Pengujian pada komponen siklus perubahan kas terhadap nilai perusahaan sesuai dengan teori efisiensi manajemen modal kerja [1]. Periode piutang dan periode persediaan terhadap nilai perusahaanmendukung hasil penelitian yang menunjukkan bahwa efisiensi pada manajemen 
piutang dan persediaan dapat meningkatkan nilai perusahaan [17].Periode utang juga ditemukan memiliki pengaruh positif signifikan terhadap nilai perusahaan memberikan hasil yang lebih baik daripada hasil penelitian yang ditemukan sebelumnya [9][12][17]. Pengaruh yang signifikan dapat diartikan bahwa penilaian investor sangat mempertimbangkan bagaimana perusahaan mengelola modal kerjanya serta investor akan memberikan penalti jika perusahaan tidak melakukan efisiensi [9].

Peneliti terdahulujuga menjelaskan bahwa penurunan periode piutang dan periode persediaan akan berdampak pada perbaikan kinerja perusahaan [17]. Dengan mengurangi periode piutangnya perusahaan dapat memperbaiki likuiditasnya sehingga berkesempatan untuk berinvestasi di bisnis baru yang masih dapat berkembang. Selain itu, pengurangan periode piutang menunjukkan bahwa perusahaan memiliki hubungan serta komunikasi yang baik secara jangka panjang dengan pelanggannya karena adanya perbaikan berkelanjutan dari kedua belah pihak. Penurunan periode persediaan juga menunjukkan adanya upaya perusahaan untuk memperbaiki likuiditasnya. Penurunan periode persediaan terjadi jika perusahaan telah memiliki basis pelanggan yang kuat dan stabil sehingga lebih mudah untuk memprediksi permintaan produk atau. Perusahaan dengan kondisi likuiditas yang lebih baik karena penerapan efisiensi manajemen modal kerja, tentu akan dinilai memiliki kinerja yang baik di mata investor [26].
Perpanjangan periode utang dapat meningkatkan nilai perusahaan secara signifikanmenunjukkan bahwa perusahaan sektor industri barang konsumsi di Indonesia menggunakan utang usahanya sebagai salah satu alternatif pembiayaan investasinya. Hal tersebut membuktikan perusahaan di negara berkembang memanfaatkan utang dagang untuk mempercepat pertumbuhan perusahaan [3]. Namun hasil yang hanya signifikan pada $10 \%$ ini juga memberikan penjelasan bahwa investor menekankan perusahaan agar lebih hati-hati ketika melakukan perpanjangan periode utang dagangnya dengan mempertimbangkan risikonya.

Gambar 4 memberikan penjelasan hasil penelitian bahwa profitabilitas perusahaan memiliki pengaruh positif signifikan terhadap nilai perusahaan yang juga sesuai dengan toeri yang diungkapkan oleh Fama dan French [2] bahwa nilai perusahaan akan meningkat seiring dengan meningkatnya profitabilitas perusahaan. Hasil pengujian tersebut juga mendukung hasil yang diperoleh penelitian terdahulu [10][28][29]. Jika perusahaan mampu menunjukkan prospek laba yang baik dari investasi yang dilakukannya, investor akan memberikan apresiasi positif yang tercermin pada tingginya harga saham perusahaan. Pengaruh profitabilitas akan berpengaruh sangat signifikan terhadap nilai perusahaan selama perusahaan memiliki kebijakan dividen yang stabil dan dapat diprediksi [1].

Tabel 7. Perbandingan Pengaruh Langsung dan Tidak Langsung

\begin{tabular}{|c|c|c|c|c|}
\hline \multirow{4}{*}{ Pengaruh Antar Variabel } & \multicolumn{4}{|c|}{ Pengaruh Kausal } \\
\hline & \multirow{3}{*}{ Langsung } & \multicolumn{3}{|c|}{ Tidak Langsung } \\
\hline & & \multirow{2}{*}{ Melalui Profitabilitas } & \multicolumn{2}{|c|}{ Uji Sobel } \\
\hline & & & T-Hitung & Sig. \\
\hline $\mathrm{X}_{1}$ ke $\operatorname{LnY}$ & $-0,331$ & $0,251 \times 0,398=0,100$ & 1,856 & 0,063 \\
\hline $\operatorname{Ln} X_{2}$ ke $\operatorname{Ln} Y$ & $-0,197$ & $0,098 \times 0,398=0,039$ & 1,737 & 0,082 \\
\hline $\operatorname{Ln} X_{3}$ ke $\operatorname{Ln} Y$ & 0,150 & $0,270 \times 0,398=0,107$ & 1,870 & 0,062 \\
\hline \multicolumn{5}{|c|}{ T-tabel $(0,05 ; 114) 1,981$} \\
\hline
\end{tabular}

Sumber: Data diolah, 2015

Tabel 7 menjelaskan pengaruh tidak langsung pada komponen siklus perubahan kas terhadap nilai perusahaan melalui profitabilitas tidak dapat mendukung teori yang menyatakan bahwa profitabilitas perusahaan meningkat karena adanya efisiensi manajemen modal kerja, maka peningkatan profitabilitas tersebut juga meningkatkan nilai perusahaan [1][2][18]. Hal ini ditunjukkan dengan hasil nilai perkalian koefisien tidak langsungnya lebih kecil daripada nilai koefisien langsungnya terlepas dari arah hubungannya. Hasil dari Uji Sobel juga menunjukkan nilai signifikansi di atas $5 \%$ yang berarti profitabilitas tidak memediasi hubungan antar variabel penelitian.

Terdapat beberapa alasan profitabilitas tidak dapat memediasi pengaruh periode utang, periode persediaan dan periode utang terhadap 
nilai perusahaan. Pertama, investor lebih memperhatikan bagaimana perusahaan menjaga likuiditasnya secara langsung daripada hanya sekadar menilai dari profitabilitasnya saja, karena likuiditas yang tinggi menggambarkan bahwa perusahaan memiliki kinerja yang baik [26]. Kedua, adanya perbedaan sikap antara perusahaan dengan investor yangditinjau dari penilaian profitabilitasnya, perusahaan cenderung melakukan peningkatan penggunaan modal kerjanya untuk meningkatkan labanya. Ditinjau dari penilaian pasar, investor lebih menginginkan jika perusahaan melakukan efisiensi manajemen modal kerjanya untuk menjaga likuiditasnya. Peningkatan profitabilitas karena peningkatan penggunaan modal kerja menjadi tidak berarti dalam penilaian investor terhadap perusahaan. Ada dugaan bahwa jika perusahaan dan investor memiliki sikap yang sama dalam mengelola modal kerja, profitabilitas dapat memiliki pengaruh mediasi yang signifikan.

\section{KESIMPULAN}

Efisiensi memang diperlukan dalam manajemen modal kerja, tetapi tetap mempertimbangkan efektivitasnya. Peningkatan penggunaan jumlah modal kerja tidak selalu berarti bahwa perusahaan memiliki manajemen yang buruk. Perusahaan yang sedang berkembang seperti yang terjadi pada perusahaan industri barang konsumsi di Indonesia umumnya perlu menambah penggunaan jumlah modal kerjanya untuk meningkatkan penjualannya selama pertumbuhan peningkatan modal kerjanya tidak melebihi pertumbuhan penjualannya. Namun, perlu ada upaya dari perusahaan untuk menjaga keseimbangan antara tingkat likuiditas dan profitabilitas agar dapat memaksimalkan nilai perusahaan di pasar.

\section{SARAN}

Penelitian ini berusaha untuk membuktikan pengaruh tidak langsung antara komponen siklus perubahan kas terhadap nilai perusahaan melalui profitabilitas yang belum diteliti oleh penelitian terdahulu, tetapi belum mendapatkan hasil yang diinginkan karena adanya perbedaan sikap antara perusahaan dan investor terkait manajemen modal kerja. Diharapkan penelitian berikutnya dapat mengembangkan penelitian yang lebih baik untuk dapat membuktikan hal tersebut dengan menggunakan objek lainnya. Penelitian selanjutnya diharapkan tidak hanya meneliti variabel terkait internal perusahaan saja, tetapi juga melibatkan faktor eksternal seperti siklus bisnis, inflasi, pertumbuhan ekonomi maupun suku bunga.

\section{UCAPAN TERIMA KASIH}

Kami mengucapkan terima kasih kepada Ibu Nur Khusniyah dan Ibu Siti Aisjah yang telah memberikan kritik dan saran terhadap penelitian ini.

\section{DAFTAR PUSTAKA}

[1]. Brigham, E. F. dan Ehrhardt, M. C. 2011. Financial Management: Theory and Practice. $13^{\text {th }}$ edition. South-Western Cengage Learning. USA.

[2]. Fama, E. F. dan French, K. R.. 2000. Testing Tradeoff and Pecking Order Predictions About Dividends and Debt. The Center for Research in Securities Prices Working Paper, No.506, December 2000.

[3]. Vernimmen, P.,Quiry, P., Dallochio , M., Fur, Y.L. danSalvi, A. 2009. Corporate Finance: Theory and Practice. $2^{\text {nd }}$ edition. John Wiley \& Sons, Ltd. UK.

[4]. Deloof, Marc. 2003. Does Working Capital Management Affect Profitability of Belgian Firms. Journal of Business Finance and Accounting 30 (3 \& 4): 573-587.

[5]. Tragistina, V. N. 2013. Saham Sektor Konsumsi Tulang Punggung Bursa. http://investasi.kontan.co.id/news/sahamsektor-konsumsi-tulang-punggung-bursa. Diakses tanggal 21 Desember 2014.

[6]. Wulandari, A. 2012. Prospek Saham 2013: Perbankan, Barang Konsumsi dan Properti Menjanjikan.http://market.bisnis.com/read /20121031/190/102428/ prospek- saham2013-perbankan-barang-konsumsi-andproperti-menjanjikan. Diakses tanggal 21 Desember 2014.

[7]. Badan Pusat Statistik. 2014. Produk Domestik Bruto Per Kapita, Produk Nasional Bruto Per Kapita dan Pendapatan Nasional Per Kapita, 2000-2013 (Rupiah). http://www.bps.go.id/tab_sub/view.php?ta bel=1\&id_subyek=11\&notab=76. Diakses tanggal 5 November 2014.

[8]. Enqvist, J., Graham, M. dan Nikkinen, J. 2014. The Impact of Working Capital Management on Firm Profitability in Different Business Cycles: Evidence from Finland. Research in International Business and Finance 32: 36-49.

[9]. Abuzayed, Bana. 2012. Working Capital Management and Firm's Performance in Emerging Market: The Case of Jordan. 
International Journal of Managerial Finance. Vol.8, No.2 p.155-179.

[10]. Nurjanah, P. D. 2014. Pengaruh Modal Kerja dan Struktur Modal terhadap Profitabilitas dan Nilai Perusahaan (Studi pada Sektor Aneka Industri yang Terdaftar di Bursa Efek Indonesia (BEI) Periode 2009-2012). Tesis. Program Magister Ilmu Administrasi Bisnis. Program Pascasarjana Fakultas Ilmu Administrasi Universitas Brawijaya. Malang.

[11]. Mohammad, N. E. A. B. dan Mohd Saad, N. B. 2010. Working Capital Management: The effect of Market Valuation and Profitability in Malaysia. International Journal of Business and Management 5(11): 140-145.

[12]. Vural, G., Sokmen, A. G. dan Cetenak, E. H.. 2012. Affects of Working Capital Management on Firm's Performance: Evidence from Turkey. International Journal of Economics and Financial Issues 2(4): 488495.

[13]. Tauringana, V. dan Afrifa, G. A.. 2013. The Relative Importance of Working Capital Management and Its Components to SME's Profitability. Journal of Small Business and Enterprise Development 20(3): 453-469.

[14]. Ukaegbu, B. 2014. The Significance of Working Capital Management in Determining Firm Profitability: Evidence from Developing Economies in Africa. Research in International Business and Finance 31: 1-16.

[15]. Vahid, T. K., Elham, G., Mohsen, A. K. Mohsen, danMohammadreza, E. 2012. Working Capital Management and Corporate Performance: Evidence from Iranian Companies. Procedia-Social and Behavioral Sciences 62: 1313-1318.

[16]. Lazaridis, I. dan Tryfonidis, D. 2006. The Relationship Between Working Capital Management and Profitability of Listed Companies in The Athes Stock Exchange. Journal of Financial Management and Analysis 19(1): 26-35.

[17]. Kroes, J. R. dan Manikas, A. S.. 2014. Cash Flow Management and Manufacturing Firm Financial Performance: A Longitudinal Perspective. International Journal Production Economics 148: 37-50.

[18]. Almeida, J. R. D. dan Eid, W. 2014. Access to Finance, Working Capital Management and Company Value: Evidences from Brazilian Companies Listed on BM\&FBOVESPA. Journal of Business Research 67: 924-934.
[19]. Solimun. 2002.Multivariate Analysis: Structural Equation Modelling Lisrel dan Amos. Universitas Negeri Malang. Malang.

[20]. Preacher, K. J. 2010. Calculation for The Sobel Test: An Interactive Calculation Tool for Mediation Test. http://quantpsy. org/sobel/sobel.htm. Diakses tanggal 8 Februari 2015.

[21]. Ghozali, I. 2009. Ekonometrika Teori, Konsep dan Aplikasi dengan SPSS 17. Universitas Diponegoro. Semarang, Indonesia.

[22]. Stevenson, J.W. 2009. Operations ManagementInternational Student Edition, Tenth Edition. Mc Graw Hill, Inc. USA.

[23]. Bougheas, S., Mateut, S. and Mizen, P. 2009. Corporate Trade Credit and Inventories: New Evidence of A Trade-off from Accounts payable and Receivable. Journal of Banking and Finance 33: 300-307.

[24]. Ferrado, A. dan Mulier, K. 2013. Do Firms Use Trade Credit Channel to Manage Growth?. Journal of Banking and Finance 37: 30353046.

[25]. Kling, G., S. Y. Paul dan Gonis, E.. 2014. Cash Holding, Trade Credit and Access to ShortTerm Bank Finance. International Review of Financial Analysis 32: 123-131.

[26]. Candra, T. 2009. Pasar Modal dan Karakteristik Investor Indonesia: Kasus Bursa Efek Jakarta. Jurnal Aplikasi Manajemen 7(1).

[27]. Chen, Li-Ju and Chen, Shun-Yu. 2011. The Influence of Profitability on Firm Value with Capital Structure as The Mediator and Firm Size and Industry as Moderators. Investment Management and Financial Innovation. Vol.8, No.3 p.121-129.

[28]. Rizqia, D. A. 2013. Pengaruh Managerial Ownership, Financial Leverage, Profitability, Firm Size dan Investment Opportunity terhadap Dividend Policy dan Firm Value (Studi Pada Perusahaan Manufaktur yang Terdaftar di BEI). Tesis. Program Magister Manajemen, Program Pascasarjana Fakultas Ekonomi dan Bisnis Universitas Brawijaya. Malang. 